\title{
Household Waste Management for the Achievement Efforts of SDGs in Bulak Surabaya
}

\author{
Sindy Rukmana Pratiwi, F. Rooslan Edy Santosa
}

Narotama University, Surabaya

Rukmana.sindy@gmail.com

\begin{abstract}
The purpose of this study was to determine the conductor description of household waste management in the district of Bulak Surabaya by using studies EHRA (Environmental Health Risk Assessment) where a study of participation in the District/City to understand the conditions of sanitation facilities and hygiene as well as societal attitudes on a household scale. This research was conducted by observation and interview. And the Village of respondents as an area of studyassigned randomly. Based upon the results of studies EHRA research in District of Bulak Surabaya , there are 200 respondents, only a small proportion of respondents who perform household waste management around $19.5 \%$, while those who do not perform household waste management, $80.5 \%$ ofachievement SDGs taken from point 6 "Water and sanitation" where trash organic collected in TPS (temporary disposal sites) can be treated bymade as an organic fertilizer so that the waste that goes to landfill is reduced by 40 tons a day.
\end{abstract}

Keywords: waste management, EHRA, SDGs

\section{INTRODUCTION}

SDGs (Sustainable Development Goals) is a new development that encourage change towards sustainable development by mutual agreement. Of the 193 countries that participated in the United Nation, Indonesia demonstrated high commitment to succeed in achieving the 17SDGs destination on July 4, 2017, the signing of the Presidential Decree 59 Year 2017 on the Implementation of Sustainable Development Goals.

In Indonesia, the population growth that is very significant in every year causing the waste generated from the activity and consumer spending also increased. According to Kardono (2007) reported annually Indonesia has increased the volume of waste as much as $2-4 \%$. Garbage derived from activities of household activities, industry and trade.

Trash with large numbers also pose a threat of environmental pollution, such as flooding until the outbreak of the disease.According to the Ministry of Environment (2008), in Indonesia the majority of incoming waste classified as organic waste from the whole is $58 \%$ while plastic waste $14 \%$ and paper waste as much as $9 \%$. In the area of Surabaya, population growth increases significant, as a result of population growrh in every year that often lead to waste resulting from the activity and consumer spending also increased Approximately 1,200 tonnes / day of waste collected in this city.According to journalist Ahmad Faizal at Reuters TV, a lot of unsorted household waste disposal. "Mayor of Surabaya, Tri Rismaharini, claims due to 'treatment' special against garbage, supply of garbage from the traditional market in Surabaya that goes to landfill was reduced by 40 tons a day". Kenjeran region Surabaya, Surabaya contained herein Super depot Sutorejo waste from separated according to its kind that is organic and nonorganic. Most of the organic waste is channeled in home composting in Surabaya, whereas for the non-organic garbage partially recycled. Of 1,200 tons per day is around $20 \%$ of

Household Waste Management for the Achievement Efforts of SDGs in Bulak Surabaya

Sindy Rukmana Pratiwi, F. Rooslan Edy Santosa 
incoming waste in composting house that can be processed into compost for the plants in the garden city, for the remainder of that management were thrown in the landfill.

Environmental health risk assessment study (EHRA) is a study to understand the conditions of sanitation and hygiene facilities as well as the behavior of people in the household. EHRA study focuses on sanitation facilities and people's behavior, such as drinking water, garbage disposal services, latrines and sewerage households.

\section{RESEARCH METHODS}

\section{A. Research Sites}

The location of research conducted in the District of Bulak, District Bulak including North Surabaya. The location of the research will focus on the sanitation sub district. (According to the District of Bulak in number 2017) District of Bulak has an area of $6.72 \mathrm{~km}^{2} \pm$ there are four village, the village Bulak, Village Kedung Cowek, New Sukolilo Village, and Village Kenjeran there are 21 neighborhoods and 131 RT,

Collecting data in this study is looking for information that is primary or secondary. Primary data were obtained from field observation activities, distribution of questionnaires, drawing documentation, and interviews. The interview in question is by asking questions directly to the Community District of Bulak by way of question and answer, and the data retrieved from the rules laid out in the questionnaire EHRA.

Secondary data in this study come from the archives that can be obtained from Surabaya BPS data, or books from previous research that can support researchers in analyzing the problems studied.

This research is qualitative and quantitative, qualitative research which aims to understand the areas studied, such as behavior, action, or describe and explain the quality of social influences that can not be described, and measured or portrayed through a quantitative approach.

For determining the number of samples is a very important part to do research. In ERHA study to determine the minimumsample size can use theSlovin formula. The purpose of determining the type of samples used to determine estimates of the proportion of the population using the sample proportion.

Slovin formula as follows:

$n=\frac{N}{1+N e^{2}}$

Info:

$\mathbf{n}$ is the number of samples

$\mathbf{N}$ is the number of population

$\mathbf{e}$ is the sampling error is allowed

Bulak sub-district has a total population of 42978 inhabitants. With a degree of confidence on research by $90 \%$, then the error rate of $10 \%$. By using the formula Slovin and with a margin of error of $10 \%$, obtained 99.9 number of samples, because the provisions of each village should be taken 40 samples in the study and in the district bulak EHRA there are 5 villages each district is required so that the 200 respondents said the data is valid.

\section{RESULTS AND DISCUSSION}

Respondents information in this study are described according to the group, the respondent's age, status-occupied homes, the respondents' education, ownership of the poor (SKTM), possession of a health insurance card (JAMKESDA), and possession of child respondents. It is very necessary because of the linkage with sanitation problems in the neighborhood. Sanitation facilities needs associated with the number of people who stay at home, therefore, the more the number of families who stay at home, the greater the required capacity and heavier loads also sanitation.

Based on the results of EHRA studies that have been done, the number of respondents aged over 45 years is positioned on the highest $37 \%$, with the number of 73 respondents. While most of the status of their own homes and that $77 \%$ to 155 the number of respondents. this is very important information where the consequences of this condition lies in

Household Waste Management for the Achievement Efforts of SDGs in Bulak Surabaya

Sindy Rukmana Pratiwi, F. Rooslan Edy Santosa 
the availability of household sanitation facilities. Of the $23 \%$ of respondents who occupied the house does not belong to themselves tendnotto adjust sanitary facilities according to their needs and they also tend to have a low environmental awareness.

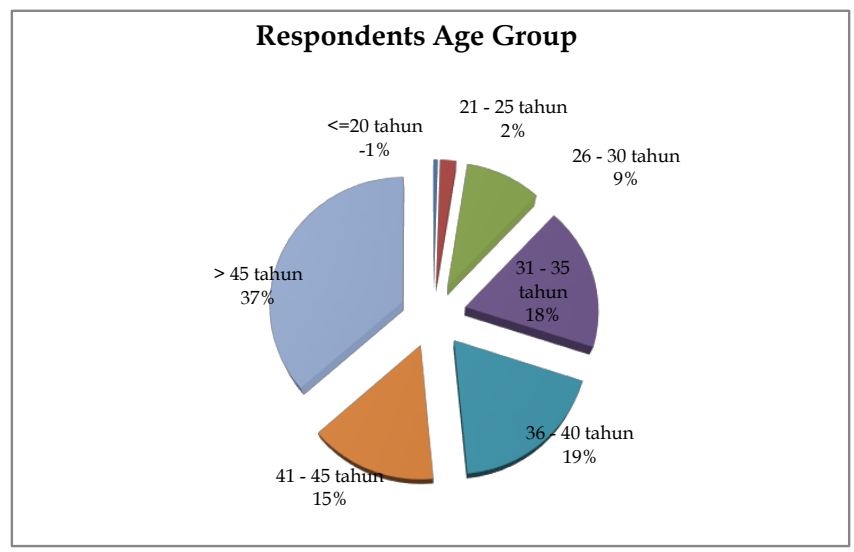

Picture 1.Respondents Age Group

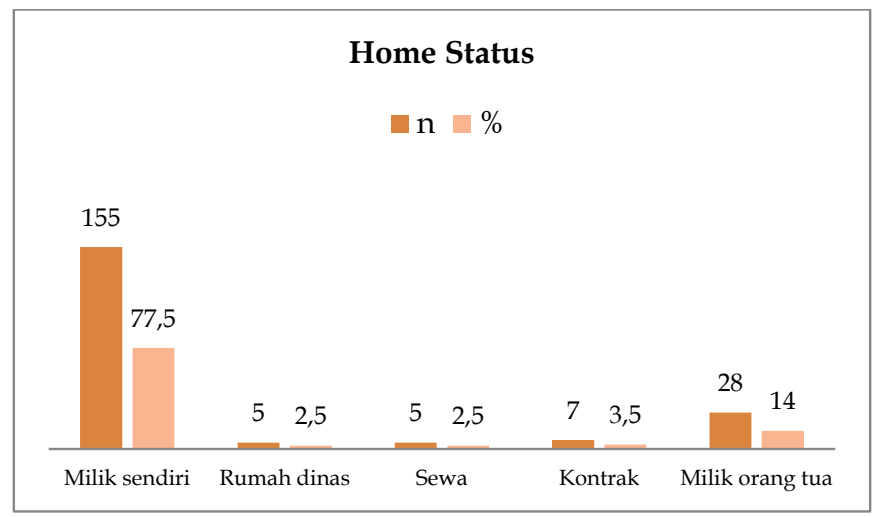

Figure 2.Home Status

For the last educational status of respondents the high school level have the highest percentage to $34 \%$, with the number of 68 respondents. The level of education is a very important factor which had an impact on understanding and awareness of the sanitation infrastructure and facilities that exist in the environment. The higher educational level, the greater information obtained and also have a high awareness of environmental hygiene and solid waste management.

Household Waste Management for the Achievement Efforts of SDGs in Bulak Surabaya 


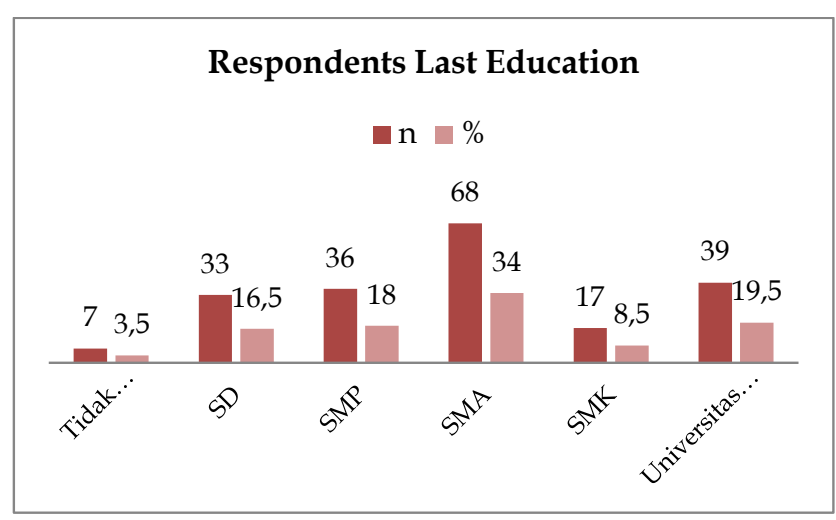

Figure 3.Respondents Last Education

Based on the information obtained that the respondents who have a certificate can not afford (SKTM) by $17 \%$. While respondents who had health insurance cards for poor families (ASKESIN) amounted to $60.5 \%$.For the respondents who have children in the home by $90 \%$.

\section{A. Household Waste Management}

Trash in environmental conditions bulak the District of the city of Surabaya in total the highest indicator is given by the number of mosquitoes in the region amounted to $88.5 \%$ with the number of 177 respondents. Conditions garbage that were in the area is still a lot of carriers of germs.

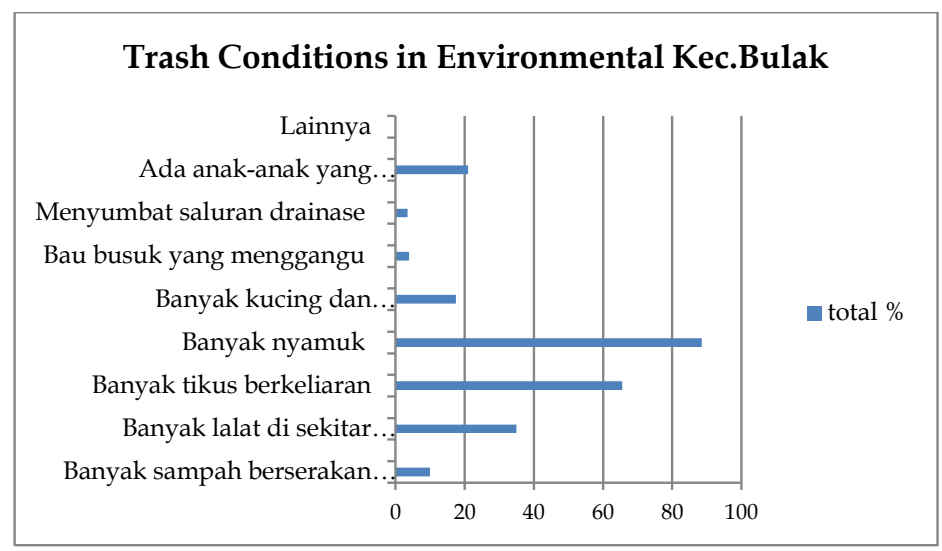

Figure 4. Trash Conditions in Environmental Kec.Bulak

Respondents who perform household waste management to be collected and disposed to landfills while (TPS) amounted to $98.5 \%$. while carrying out waste management in a way is collected by informal collectors who recycle $1.5 \%$.

Household Waste Management for the Achievement Efforts of SDGs in Bulak Surabaya

Sindy Rukmana Pratiwi, F. Rooslan Edy Santosa 
Pattern garbage collection by Aswadi Mohammed et al (2011) is using direct communal pattern, where garbage collection is done by the people to the polling station or directly to the truck that came to the collection point.

Based on the studies obtained, respondents who expressed a sorthing waste are around $80.5 \%$ with the number 161 of the 200 respondents, while sorting the garbage that is $19.5 \%$ with 39 of the 200 respondents jumalah. Actual sorting of waste must be done because of the segregation of garbage, residents of each village are also invited to assist in the risk of environmental pollution caused by waste from waste that contain hazardous substances and toxins. with this separation of the species suspected to contain hazardous materials can be separated and handled specially.

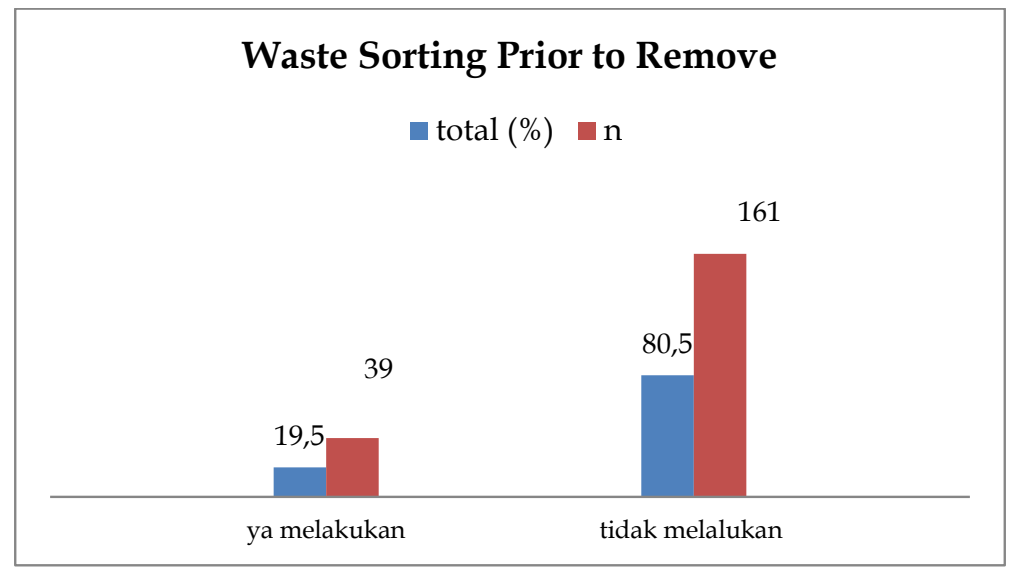

Figure 5. Waste Sorting Prior to Remove

Based on waste sorting is done in the District of Bulak, that the respondent through the trash, organic or wet waste by $53.8 \%$ with the number of 21 respondents. Based on research from the Department of Health Surabaya City Government (2015) Part of North Surabaya area, Bulak and Kedung Cowek were categorized at very high risk villages, so it is necessary to get the attention and priorities of the government of Surabaya in the construction of development programs and activities related to sanitation.

Household Waste Management for the Achievement Efforts of SDGs in Bulak Surabaya

Sindy Rukmana Pratiwi, F. Rooslan Edy Santosa 


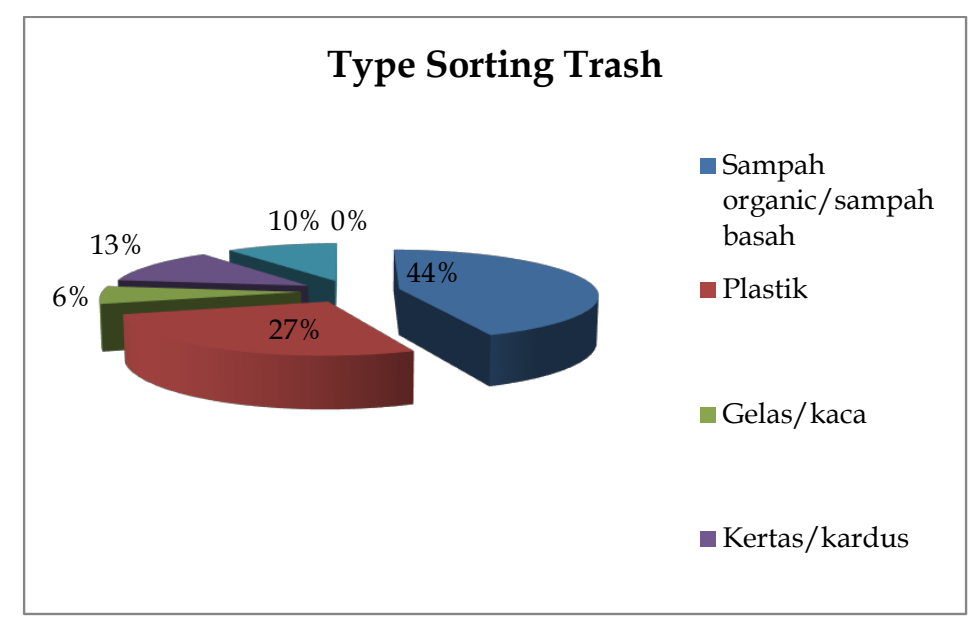

Figure 6. Type Sorting Trash

Most of the District bulak, transporting waste by officers carried out several times a week by $72.5 \%$ with the number of 145 respondents. As for the transport of waste every day amounted to $27.5 \%$ with the number of 55 respondents. Transporting waste carried by the officers associated with the prices already set in their respective territories.

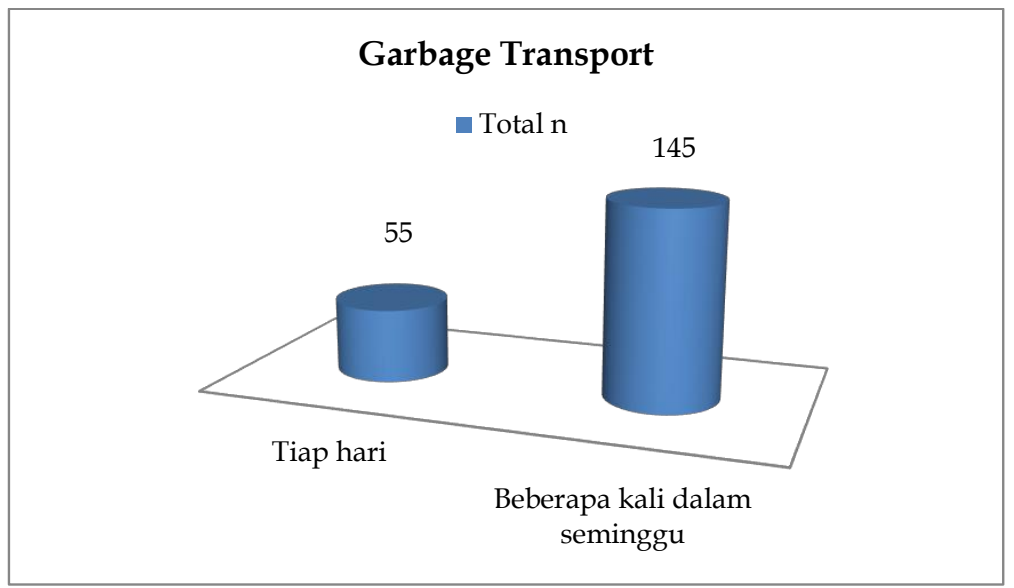

Figure 7. Garbage Transport

\section{CONCLUSION}

Territory District of Bulak community have not done the maximum waste management, where only some percent of respondents who pick through the trash, there are still people who use plastic bags as a garbage, and not putting wastes in the right place. Based upon the results of the EHRAstudies researchin District of Bulak Surabaya, there are 200 respondents, only a small proportion of respondents who undertake waste management such as collecting plastic bottles, collecting former box, and glass with a percentage around $19.5 \%$ with the number of 39 respondents, while not doing it around $80.5 \%$ with the number of 161 respondents.

Household Waste Management for the Achievement Efforts of SDGs in Bulak Surabaya

Sindy Rukmana Pratiwi, F. Rooslan Edy Santosa 
Construction of this district in addition to a positive impact can also negatively affect to the socio-economic life of society in the region. Society in this region are generally only have a very simple provision of education and health behavior tend to be relatively low in this region. This is a challenge for the government of Surabaya in waste management to realize the clean and healthy city.

The Achievements of SDGs in this study were taken in point 6 Water and sanitation where the mayor of Surabaya has a special treatment of waste, so the waste that goes to landfillwas reduced by 40 tons a day.

\section{REFERENCES}

Aswadi, Muhammad.dkk. 2011. Waste Management Planning at the Housing Tavanjuka Mas. Tadukalo.Vol.13 University civil engineering journal, No02. Tadulako, Palu.

Health Department of Surabaya City Government. The final report of the study EHRA Surabaya (2015). Jl.jemursari No. 27, Surabaya.

Kardono, 2007. Integrated solid waste management in Indonesia. Proceedings of the International Symposium on Ecotopia Science 2007, ISETS07: 629 - 633. Jakarta.

Bulak sub-district in 2017. The Central Statistics Agency figures Surabaya BPS- Statistics of Surabaya Municipality. Kecamata Bulak. City of Surabaya.

Ministry of Environment (2008). Indonesian Domestic Solid Waste Statistics Year 2008. Ministry of Environment of the Republic of Indonesia.

Rizal, Muhammad. 2011. Analysis of Urban Waste Management. SMARTek Journal, Vol. 9 No. 2. May 2011:
155
172
Sigi
regency,
Central

Sulawesi.http://jurnal.untad.ac.id/jurnal/index.php/SMARTEK/article/view File / 61 4/532 Downloaded 5 November 2018 . 